\title{
Influence of Genotype and Hen Age on the Egg Shape Index
}

\author{
Ahmed Sami Shaker ${ }^{1, *}$, Shahla Mohammed Said Kirkuki ${ }^{2}$, Shangaberry Rawf Aziz ${ }^{1}$, \\ Bakhan Jalil Jalal ${ }^{1}$ \\ ${ }^{1}$ Department of Animal Production, Agricultural Research Centre, Sulaimani, Iraq \\ ${ }^{2}$ Faculty of Animal Production, Sulaimani University, Sulaimani, Iraq
}

Email address:

kosrat_ahmed@yahoo.com (A. S. Shaker)

${ }^{*}$ Corresponding author

To cite this article:

Ahmed Sami Shaker, Shahla Mohammed Said Kirkuki, Shangaberry Rawf Aziz, Bakhan Jalil Jalal. Influence of Genotype and Hen Age on the Egg Shape Index. International Journal of Biochemistry, Biophysics \& Molecular Biology. Vol. 2, No. 6, 2017, pp. 68-70. doi: $10.11648 /$ j.ijbbmb.20170206.12

Received: September 3, 2017; Accepted: September 28, 2017; Published: November 8, 2017

\begin{abstract}
Shape index was a good indicator to characterize species as well as for egg quality. It seems that shape index affected by genetic and environment factors. In this study, the aim was to determine the influence of genotype and age on the shape index. A total of 789 eggs were collected from four genetic lines (Black, Black with brown neck, White Shank feather and White non-Feathering shank) of the Kurdish Chickens when the hens $52-65$ week-old. Results indicated that significant differences were observed between the four genetic lines in shape index. White non-feathering shank (WNFS) followed by Black with brown neck (BBN) significantly $(\mathrm{P} \leq 0.05)$ had higher shape index compared with Black $(\mathrm{B})$ and White shank feather (WSF). Moreover, shape index did not significantly affected by interaction between different breeds and different period's age (week) due to the uniform of egg shape and because it falls within the normal range.
\end{abstract}

Keywords: Local Chicken, Shape Index, Genetic, Breadth, Length

\section{Introduction}

Shape index (SI) is the ratio obtained by dividing maximum egg width by maximum egg length and multiply by quotient by 100 [17]. Eggs are indicated by three shapes as Sharp, normal, and round if they have and shape index values $72<$, between 72 and 76 , and $>76$ respectively. It is considered as an important factor to characterize species of birds [25], as well as an indicator for the egg quality [16], and in addition to that (SI) is very important for chick survival [12]. It seems that (SI) effected by Genetic selection [3], time of oviposition [22, 26], cluch size [6], hen age [24], and hatchability [4, 11, $17,18]$. On the other hand (SI) value affected by rupture force $[2,21]$. In poultry the heritability value of egg breadth is the highest of all external traits [5], ferthermore it seems to be a good indicator to recognize within species and with species [7] by using (SI).

Since egg shape is a quantitative character and little has been published on the influence of genetic lines and age upon the shape of the egg The objective of this study was to study the influence of genotype and age on the (SI).

\section{Materials and Methods}

\subsection{Study Area}

The current experiment was carried out in May 2015 in the poultry production department, Agricultural Research Center in Sulaimani, Ministry of Agriculture and Water Recourses in Kurdistan-Iraq, with in latitude $\left(\begin{array}{lll}35^{\circ} & 32 & 30\end{array}\right)$ north and longitude $\left(45^{\circ} 2100\right)$ east at of $(737.5 \mathrm{M})$ above sea level.

\subsection{Data Collection and Procedure}

Four genetic lines namely Black (B), Black brawn neck $(\mathrm{BBN})$, White shank feather (WSF), and White non- 
feathering shank (WNFS) used in this experiment, and the rear conditions briefly explained by [23] and the chicken fed used in current experiment were descripted by $[1,10]$. (789) fresh fertilized eggs was collecting under mating ratio of 3 dam: 1 sire (i.e. 6 dam, 2 sire for B; 6 dam, 2 sire for $\mathrm{BBN} ; 3$ dam, 1 sire for WSF; and 6 dam, 2 sire for WNFS), when hens were 52-65 week-old, comparising 213, 217, 89, 270 collecting from B, BBN, WSF, and WNFS respectively. After collection a venine caliper with accuracy of $0.01 \mathrm{~mm}$ was used to determine the egg length and breadth to calculate Shape index (SI) by the equation [20] below:

$$
\text { Shape index }(S I)=\text { Breadth } / \text { Length } \times 100
$$

\subsection{Data Analysis}

Data were analyzed by using descriptive statistic of SPSS/PASW statistics for windows version 19. One-way analysis of variance was used to test the effect of genetic lines and ages. Also Duncan's multiple range test [8] was used to test the difference between means.

\section{Results and Discussion}

Table (1) was shown the mean, standard error, standard deviation and P-value for the four genetics lines. According to results of general linear model analyses SI values ranged from $(69.81$ - 78.18, 70.16 - 80.25, 68.87 - 78.99, and 71.28 $82.91)$ in $\mathrm{B}, \mathrm{BBN}, \mathrm{WSF}$, and WNFS respectively. SI was high in white non-feathering shank (77.00 \pm 0.23$)$, intermediate in black with brown neck $(75.39 \pm 0.23)$, and low in both black and white with shank feather $(73.81 \pm 0.23$, $73.88 \pm 0.24)$ respectively. Results revealed there were significant differences between the genetic lines except between black and white with shank feather $(p<0.05)$. The result was approximate to what $[14,23]$ obseved in their studies by using same genetic lines and $[9,15,27]$ founded differences in the shape index values between the breeds they used. Also [26] obseved that the intraction between the genotype and time of oviposition could be influence the shape index value.

Table 1. Effect of genotype on shape index value.

\begin{tabular}{|c|c|c|c|c|c|c|}
\hline Genetic lines & $\mathbf{N}$ & Mean & S.E. & S.D & Min. & Max \\
\hline Black (B) & 213 & $73.81^{\mathrm{c}}$ & .23 & 1.64 & 69.81 & 78.18 \\
\hline Black with brown neck (BBN) & 217 & $75.39^{b}$ & .23 & 1.78 & 70.16 & 80.25 \\
\hline White with shank feather (WSF) & 89 & $73.88^{c}$ & .24 & 2.29 & 68.87 & 78.99 \\
\hline P-value & & .000 & & & & \\
\hline
\end{tabular}

${ }^{\mathrm{a}-\mathrm{c}}$ indicate significant differences between genotype.

As it shows in Table (2) the interaction between ages in week with genotype. No significant differences were observed between ages $(p>0.05)$ for all the genetic lines due to the uniform of egg shape who high positively correlated with the breadth that has high heritability, and also because it falls within the normal range. Age of hen was significant factor affecting the shape index as [19] found in his study when the age at 36 weeks of age, whereas significantly lower at 40 weeks of age. And the shape index at 28 and 32 weeks did not show any significant variation. The shape index determined in current study was similar out by [23]. The differences among the egg shape index that found by several studies may due to the variation in genetic and environments factors.

Table 2. Effect of age (in week) for the four genetic lines on the shape index.

\begin{tabular}{|c|c|c|c|c|c|c|c|c|}
\hline \multirow{4}{*}{$\begin{array}{l}\text { Period (week) of } \\
\text { production }\end{array}$} & \multicolumn{8}{|c|}{ Genetic lines } \\
\hline & \multicolumn{2}{|l|}{ B } & \multicolumn{2}{|l|}{ BBN } & \multicolumn{2}{|l|}{ WSF } & \multicolumn{2}{|l|}{ WNFS } \\
\hline & \multicolumn{2}{|l|}{$N=213$} & \multicolumn{2}{|l|}{$\mathrm{N}=\mathbf{2 1 7}$} & \multicolumn{2}{|l|}{$\mathrm{N}=\mathbf{8 9}$} & \multicolumn{2}{|l|}{$\mathbf{N}=\mathbf{2 7 0}$} \\
\hline & Mean & S.E & Mean & S.E & Mean & S.E. & Mean & S.E. \\
\hline 1 & $72.74^{\mathrm{bc}}$ & .72 & $73.39^{\mathrm{bc}}$ & .86 & $73.65^{\text {bc }}$ & 1.29 & $75.46 \mathrm{a}^{\mathrm{bc}}$ & 1.05 \\
\hline 2 & $72.64^{\mathrm{bc}}$ & .59 & $76.49^{\mathrm{abc}}$ & .70 & $73.16^{\mathrm{bc}}$ & .91 & $76.46^{\mathrm{abc}}$ & .86 \\
\hline 3 & $73.64^{\mathrm{bc}}$ & .59 & $74.48^{\mathrm{bc}}$ & .70 & $73.96^{\mathrm{bc}}$ & .91 & $77.39^{\mathrm{ab}}$ & .86 \\
\hline 4 & $74.52^{\mathrm{bc}}$ & .55 & $75.02^{\mathrm{abc}}$ & .65 & $74.66^{\mathrm{bc}}$ & .84 & $76.47^{\mathrm{abc}}$ & .79 \\
\hline 5 & $73.44^{\mathrm{bc}}$ & .65 & $76.65^{\mathrm{abc}}$ & .77 & $72.65^{\mathrm{bc}}$ & 1.00 & $75.95^{\mathrm{abc}}$ & .94 \\
\hline 6 & $71.31^{\mathrm{c}}$ & .72 & $75.52^{\mathrm{abc}}$ & .86 & $73.32^{\mathrm{bc}}$ & 1.11 & $74.83^{\mathrm{abc}}$ & 1.05 \\
\hline 7 & $74.08^{\mathrm{bc}}$ & .55 & $75.74^{\mathrm{abc}}$ & .65 & $73.31^{\mathrm{bc}}$ & .84 & $77.19^{\mathrm{ab}}$ & .80 \\
\hline 8 & $75.14^{\mathrm{abc}}$ & .55 & $75.09^{\mathrm{abc}}$ & .65 & $75.33^{\mathrm{abc}}$ & .84 & $77.61^{\mathrm{ab}}$ & .80 \\
\hline 9 & $73.60^{\mathrm{bc}}$ & .55 & $74.94^{\mathrm{abc}}$ & .65 & $75.86^{\mathrm{abc}}$ & .84 & $77.30^{\mathrm{ab}}$ & .80 \\
\hline 10 & $75.01^{\mathrm{abc}}$ & .83 & $77.02^{\mathrm{abc}}$ & .99 & $73.20^{\mathrm{bc}}$ & 1.29 & $76.57^{\mathrm{abc}}$ & 1.21 \\
\hline 11 & $74.95^{\mathrm{abc}}$ & .55 & $75.66^{\mathrm{abc}}$ & .65 & $73.92^{\mathrm{bc}}$ & .84 & $79.02^{\mathrm{a}}$ & .79 \\
\hline 12 & $73.64^{\mathrm{bc}}$ & .83 & $76.09^{\mathrm{abc}}$ & .99 & $72.64^{\mathrm{bc}}$ & 1.29 & $78.05^{\mathrm{ab}}$ & 1.21 \\
\hline 13 & $73.47^{\mathrm{bc}}$ & .59 & $74.78^{\mathrm{abc}}$ & .70 & $72.62^{\mathrm{c}}$ & .84 & $77.22^{\mathrm{ab}}$ & .86 \\
\hline Sig. & 0.004 & & 0.153 & & 0.243 & & 0.185 & \\
\hline
\end{tabular}

${ }^{\mathrm{a}-\mathrm{c}}$ indicate significant differences between weeks. 


\section{Conclusion}

We concluded that shape index significantly differences between the lines due to the differences in genotypes. And also there were no significant differences in shape index between the ages (week) for all the genetic lines because of the more uniform of eggs. These finds can help us to estimation of eggshell quality and estimate the chick sex before hatching depending on the shape index.

\section{Acknowledgements}

The author acknowledges the financial assistance provided by the Agricultural research center in Sulaimani for the execution of this investigation.

\section{References}

[1] Abas, K. A., Hermiz, H. N., Al-Khatib, T. R., Amin, S. M., Ahmed, A. M., \& Hamad, D. A. (2014). Comparative productive performance of local hens in Erbil-Kurdistan region. Journal of zankoy sulaimani, 16, 203-206.

[2] Ahuntas, E., \& Sekeroglu, A. (2008). Effect of egg shape index on mechanical properties of chicken eggs. Journal of Food Engineering, 85, 606-612.

[3] Anderson, K. E., Tharrington, J. B., \& Curtis, P. A. (2004). Shell characteristics of egg from historic strains of single comb white leghorn chickens and the relationship of egg shape to shell strength. International Journal of Poultry Science, 3 (1), 17-19.

[4] Asci, E., \& Durmus, I. (2016). Effect of egg shape index on hatching characteristics in hens. Turkish Journal of Agriculture-Food science and Technology, 3 (7), 583-587.

[5] Baker, C. (1960). The genetic basis of egg quality. British Poultry Science, 1 (1-3), 3-16.

[6] Barta, Z., \& Szekely, T. (1997). The optimal shape of avian eggs. Functional ecology, 11, 656-662.

[7] Buss, E. G. (1982). Genetic differences in avian egg shel formation. Poult. Sci., 61, 2048-2055.

[8] Duncan, D. B. 1955. Multiple Range and Multiple Test. Biometrics. 11: 1-42.

[9] Egahi, J. O., Dim, N. I., \& Momoh, O. M. (2013). The effect of plumage modifier genes on egg quality indices of the nigerian local chicken. Journal of Agriclture and veterinar Science, 2 (2), 04-06.

[10] Hermiz, H. N., K. A. Abas, T. R. Al-Khatib, Sh. M. Amin, A. M. Ahmed, D. A. Hamad, H. P. Denha. 2012. Effect of strain and storage period on egg quality characteristics of local Iraqi laying hens. Research Opinions in Animal \& Veterinary Sciences. pp: 98-101.

[11] Khurshid, A., Farooq, M., Durrani, F. R., Sarbiland, K., \& Manzoor, A. (2004). Hatching performance of japanese quail. Livestock Research For Rural Development, 16 (1).
[12] Lundberg, C.-A., \& Vaisanen, R. A. (1979). Selective correlation of egg size with chick mortality in the blackheaded gull (LARUS RIDIBUNDUS). Condor, 81, 146-156.

[13] Marble D. R. (1943). Genetics of Egg Shape Poult Sci 22 (1): 61-71.

[14] Mohammed, R. M., Kirkuki, S. M., Abdulla, S. S., \& Ali, S. M. (2016). Effect of three genetic groups of Kurdish local chicken and Isa brown on egg external quality and earlobe color. International Journal of Applied Biology and Pharmaceutical Techonology, 7 (1), 254-257.

[15] Monira, K. N., Salahuddin, M. and Miah, G. 2003. Effect of breed and holding period on egg quality characteristics of chicken. International Journal of Poultry Science, 2 (4): 261263.

[16] Mueller, W. J., Maw, A. G., \& Buss, E. G. (1960). The influence of season and the age of layers on egg weight, shape index, albumen quality and shell thickness. Poultry Science, 39 (4), 854-860.

[17] Narushin, V. G., \& Romanov, M. N. (2002). Egg physical characteristics and hatchability. World's Poultry Science Tournal, 58, 297-303.

[18] Pinowska, B., Barlcowska, M., Pinowski, J., Hahm, K.-H., \& Lebedeva, N. (2002). The effect of egg size on hatching rate in the tree sparrow. ACTA ornithologica, 37 (1), 7-14.

[19] Rajkumar, U. R. P. Sharma, K. S. Rajaravindra, M. Niranjan, B. L. N. Reddy, T. K. Bhattacharya and R. N. Chatterjee (2009). Effect of Genotype and Age on Egg Quality Traits in Naked Neck Chicken under Tropical Climate from India. International Journal of Poultry Science 8 (12): 1151-1155.

[20] Reddy, P., Reddy, V., Reddy, C., \& Rap, P. (1979). Egg weight shape index and hatchability in Khaki campbell duck egg. Ind. J. Poult. Sci., 14, 26-31.

[21] Richards, J. F., \& Swanson, M. H. (1965). The relationship of egg to shell strength. Poultry Science, 44 (6), 1555-1558.

[22] Roland, D. A. (1978). The relationship of egg shape to time of ovipositin and egg shell quality. Poultry Science, 57 (6), 17231727.

[23] Shaker, A. S., Hermiz, H. N., Al-Khatib, T. R., \& Mohammed, R. M. (2016). Egg shape characterization for four genetic groups of Kurdish local chickens. Food and Nutrition ScienceAn International Journal, 1, 20-25.

[24] Shultz, F. T. (1953). Analysis of egg shape of chickens. Biometrics, 9 (3), 336-353.

[25] Song, K. T., Choi, S. H., \& Oh, H. R. (2000). A comparison of egg quality of Pheasent, Chukar, Quail and Guinea fowl. Asian-Aus. J. Anim. Sci., 13 (7), 986-990.

[26] Tůmová, E., L. Zita, M. Hubený, M. Skřivan, Z. Ledvinka 2007. The effect of oviposition time and genotype on egg quality characteristics in egg type hens. Czech J. Anim. Sci., 52, 2007 (1): 26-30.

[27] Yakubu, A., D. M. Ogan and R. E. Barde. (2008). Productivity and egg quality characteristic of free range naked neck and normal feathered Nigerian indigenous chickens. International Journal of Poultry Science 7 (6): 579-585. 